\title{
In situ LA-ICP-MS study of the chlorite in Donghua, Dehua-Youxi- Yongtai ore district, SE China: volcano-magma-alteration process and implication for exploration
}

\author{
SIDA NIU ${ }^{1}$, JIAN GUO ${ }^{1}$, ZHAOQIANG HUANG ${ }^{1}$, \\ HUAYING WU ${ }^{1}$ AND FEIPENG FAN ${ }^{2}$ \\ ${ }^{1}$ Institute of Mineral Resources Research, China Metallurgical \\ Geology Bureau \\ ${ }^{2}$ Nanjing Center, China Geological Survey \\ Presenting Author: niusida@cmgb.cn
}

The Dehua-Youxi-Yongtai (DYY) ore district is located in the southern part of the Wuyi Mountain metallogenic belt, which is one of the potential areas of gold deposits and known as the "Gold Triangle" of Fujian Province, SE China. However, the DYY ore district is still at a low degree of exploration and research. In the northwest of the DYY ore district, the magmatism, dykes, faults, and Neoproterozoic metamorphic rock provide favorable advantages for the mineralization in Donghua, suggesting metallogenic potential. This study focuses on the chlorite mineral chemistry in Donghua as footprint of the volcano-magma-alteration process and the vectoring for minerlization. According to geology and the occurrences, the chlorite from Donghua can be divided into two generations: (1) chlorite I is closely related to volcanic-magmatism and alteration, developed in strata and intrusive rocks, and (2) chlorite II is accompanied with superimposed hydrothermal overprinting, often occurring as vein. The alteration process suggested by overprinting chlorite II can be regarded as almost coeval with the ca. 154-153 Ma magmatic event. According to the geothermometry of the chlorite in Donghua, chlorite I might went through a gradual cooling process. The overprinting chlorite might experience the hydrothermal/epithermal pulsing of two episodes. The geochemical behaviors of the trace element are different from the two generations of the chlorite. The distribution of elements has some regular variation with the periodic table order. From Li to Cs can be divided into the first group, while from $\mathrm{Ba}$ to $\mathrm{U}$ are divided into the second group. In the first group, chlorite I is higher than chlorite II for the majority of the elements, expect for $\mathrm{Zn}, \mathrm{Sr}$, and $\mathrm{Y}$; while for the second group, major elements for chlorite I are higher than chlorite II. Pyrite is the main mineral that contains gold in the DYY ore district. The chlorite II is accompanied with pyrite, therefore the prediction made by chlorite II can be regarded as the reference for exploration.

Acknowledgement: this study is sponsored by the National key R\&D programs of China (Grant No. 2016YFC0600210). 